\title{
Internal Microclimate: Cumulative Exergy Consumption in a Sandcrete and a Burnt Brick- Walled Structure
}

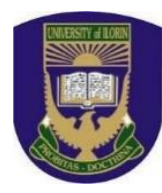

\author{
A. A. Ibrahim*, A. A. Adedeji \\ Department of Civil Engineering, University of Ilorin, Ilorin, Nigeria.
}

\begin{abstract}
Current practices of planning and designing of buildings in Nigeria do not consider the thermal comfort, the building energy and exergy demand. There is a need for better understanding of exergy analysis to improve the quality match between building energy demand and supply. The aim of this study is to estimate the exergy consumption value for a hollow sandcrete and a burnt brick-walled structure in a tropical sub-region. The properties of the building were assessed, eQuest software was used to estimate the energy demand of the respective buildings and the exergy analysis was conducted using the exergetic factor of electricity. The cumulative exergy consumptions of the existing sandcrete-walled building, the modelled sandcrete and the burnt brick-walled building were found to be 246,074.4 MJ/year, 128,646 MJ/year, and 128,595.6 MJ/year respectively. The modelled sandcrete-walled building, as well as the burnt brick-walled building, were found to be $48 \%$ more energy efficient than the existing building as a result of improving the airtightness of the building, reducing the solar heat gain, and utilizing extremely efficient systems. However, the exergy analysis suggested that the hollow burnt brick-walled building perform better than the hollow sandcrete-walled building.
\end{abstract}

KEYWORDS: Building, electricity, energy, eQuest, exergy, sandcrete.

\section{INTRODUCTION}

According to Arup and Genre (2016), microclimate is the unique climate of a small area such as a park or a neighbourhood which may be slightly different from the regional climate. Good planning and building design can make improvements to the microclimate which in turn improve conditions inside the buildings, as well as improving the outside environment (Arup \& Genre, 2016). The Microclimatic condition surrounding a building has a direct impact on the comfort of the inhabitants (Mooney \& Porter, 2010). Also, Itard (2005) holds that the occupants' habit of using a building affect the interior thermal condition, the light and electrical demand significantly. Higher urban temperatures have a key impact not only on human comfort but also on electricity demand for air conditioning (Santamouris, 2013).

Enhancing the microclimate is geared towards creating a more comfortable environment for those outdoors as well as reducing the need for cooling systems inside buildings (Arup $\&$ Genre, 2016). In Nigeria, the housing sector recorded the majority of the electricity consumption (more than 50\%) and will unavoidably surge, owing to the growing population, improvements in standards of living, and relocation of rural dwellers to urban centres (Arup \& Genre, 2016). By utilizing bioclimatic design methods with extremely efficient systems, it is conceivable to significantly decrease the energy necessary to light and cool a building, or even remove the need for cooling entirely (Arup \& Genre, 2016).

*Corresponding author: ibrahim.abdullahi39@gmail.com
Energy is the capacity to do work while the quality of energy is termed exergy. The first law of thermodynamics asserts that energy is never destroyed during a process; it changes from one form to another. In contrast, the second law of thermodynamics states that exergy is the quantity that is consumed during processes. Itard (2003) posited that in a working system, exergy is consumed, entropy is generated, while energy is conserved.

Exergy first applications to the building sector were in the 1990s (Ilari, 2007). Exergy demand of a building should be well-suited to the exergy being supplied to the building, as limiting the exergy loss could finally decrease the amount of the primary energy provided to the building (Sakulpipatsin, Itard, Van der Kooi, Boelman, \& Luscuere, 2010). Building's energy demand is based purely on physical balances between the environment and the building (Itard, 2005). Mahlia, Taufiq, Ong, and Saidur (2011) developed a methodology to conduct exergy analysis and applied it in a tropical climate on space cooling, day lighting, and electric lighting system in a room space. It was observed that the day lighting system consumed about $28 \%$ of the full exergy, the wall consumed $78 \%$ of the total exergy in the day lighting system.

The electric lighting system consumed about $6 \%$ of the exergy from the total exergy consumption of the room. The author reported that most exergy in the room was consumed by the space cooling system. Itard (2005) conducted exergy analysis on a pre-war and a modern building and observed that long-term increase in the buildings' sustainability can be 
reached by decreasing the energy demand for electrical appliances considerably and by either refining the efficiency of the electricity production process or applying a sustainable means of generating electricity based on wind or sun. Exergy leads to the conclusion that certain systems or processes are basically wrong and should be substituted by more exergy efficient ways (Sakulpipatsin, 2008). The exergy analysis enables the designer to understand the cause, identify the location, and establish the true degree of waste and loss of energy in a building. Joule is the unit of both exergy and energy.

The purpose of this research is to estimate the cumulative exergy consumption for a sandcrete-walled structure with electricity as its energy source, in a tropical sub-region considering only the computers, air conditioning systems and area lighting systems present in the structure with the aid of the eQUEST simulation software. Variants of control building were also simulated to identify measures to increase the sustainability of the specimen building.

\section{THEORETICAL ANALYSIS}

\section{A. Building Materials}

Sandcrete blocks and burnt bricks are common materials used for masonry works in Nigeria housing delivery (Adedeji \& Fa, 2012). Laaroussi, Cherki, Garoum, Khabbazi, and Feiz (2013) concluded that the use of construction materials with more favourable thermal properties greatly reduces the heat gain in a building.

\section{1) The Hollow Sandcrete Blocks}

According to Abdullahi (2005) sandcrete block is a composite material made up of cement, sand and water, moulded into different sizes. Sandcrete blocks are relatively cheap when compared to other construction materials and provide excellent resistance to damage without the added cost of protection devices (Odeyemi, 2012). Hollow sandcrete block has a thermal conductance value (U-value) of 1.6 W/m² K (Arup \& Genre, 2016).

\section{2) The Hollow Burnt Bricks}

Burnt bricks are made out of clay-bearing subsoil. Hollow bricks are not only lighter and easier to handle but also have different thermal properties according to the model and the number of holes within it (Shibib, Qatta, \& Hamza, 2013). The thermal conductivity of hollow brick that have been reported by authors are $0.346 \mathrm{~W} / \mathrm{m}^{2} \mathrm{~K}$ (Laaroussi et al., 2013), 0.60 $\mathrm{W} / \mathrm{m}^{2} \mathrm{~K}$ (Carl, 2017), and $0.64 \mathrm{~W} / \mathrm{m}^{2} \mathrm{~K}$ (Shibib et al., 2013), all of which are less than the thermal conductance value of a hollow sandcrete block.

\section{B. eQUEST Simulation Tool}

Energy performance of a structure depends on the interactions of building services systems and many building features (Lou, Tsang, Li, Lee, \& Lam, 2017). The eQUEST software is a tool developed using DOE-2 simulation engine. It performs whole building simulation analysis throughout the entire design process. Simulations comprise energy consuming devices performance and equipment as well as several ends use. Tabulated and graphic results include daylight and energy system control, energy cost estimation, automatic implementation of common energy efficiency measures, as well as energy consumption (Arup \& Genre, 2016).

\section{Electricity}

Electricity is an energy carrier of the highest quality and all of the electric energy can be used for useful work, the exergy factor for electricity is 1 (Molinari, 2009). Electricity is not a primary energy source, but must be produced using some type of primary energy and then transformed into electricity through different types of processes. Lidholm, Odelbrink, and Sandwall (2012) reported that the amount of exergy depends on how the electricity is produced which could be through the use of coal, hydropower, wind, solar, etc. The Exergy factors

Table 1. Exergy factors for some different energy sources.

\begin{tabular}{cc}
\hline Fuel & Exergy factor \\
\hline Natural gas & 0.9 \\
Fuel oil & 0.9 \\
Mineral coal & 0.9 \\
District heating at $100^{\circ} \mathrm{C}$ & 0.21 \\
Heat at $20^{\circ} \mathrm{C}$ & 0.05 \\
Electricity & 1.0
\end{tabular}

Source: (Molinari, 2009)

of different energy sources are listed in Table 1.

\section{Area Lighting System}

The quantity of lighting necessary in a space purpose and size of the space. The quantity of light required in an area is termed "LUX" level which is equivalent to lumens/area $\left(1 \mathrm{~m} / \mathrm{m}^{2}\right)$. The technical word for brightness is Lumens. The more the lumens, the brighter the light is and the more energy is consumed (Jian, 2018). Considering the comfort of the occupant, it is important to meet the required brightness of the room. To estimate the number of bulbs required in a room to meet the required lux level of that room, the equation (1) is used

$$
\text { No of bulbs }=\frac{\text { Room square area } X \text { lux level }}{\text { Lumen rating of bulb }}
$$

Energy Consumed $=$ No of bulbs $x$ bulb rating

Table 2: Guideline for comparison of bulbs.

\begin{tabular}{cccc}
\hline $\begin{array}{c}\text { Incandescent } \\
\text { (Watts) }\end{array}$ & $\begin{array}{c}\text { CFL } \\
\text { (Watts) }\end{array}$ & $\begin{array}{c}\text { LED } \\
\text { (Watts) }\end{array}$ & $\begin{array}{c}\text { Lumens } \\
\text { (Brightness) }\end{array}$ \\
\hline 40 & $8-12$ & $4-5$ & 450 \\
60 & $13-18$ & $6-8$ & 890 \\
$75-100$ & $18-22$ & $9-13$ & 1210 \\
100 & $23-30$ & $16-20$ & 1750 \\
150 & $30-55$ & $25-28$ & 2780 \\
\hline
\end{tabular}

Source: (Seaman, 2011) 
The guideline for the comparison of bulbs is shown in Table 2. Compact Fluorescent Light (CFL) bulbs contain highly toxic metals such as mercury, and when compared to LED, it gives off a significantly higher amount of heat. A CFL bulb that has been ignited for some time do become hot enough to cause discomfort. LED lights will continue to be cool to the touch because the tiny amount of heat that is emitted during the production of light is so minute that it cannot disturb the temperature of the casing (LEDlights.org, 2019).

\section{E. Sizing Air Conditioner System for a Room}

Air Conditioner (AC) equipment is measured in BTU (British Thermal Units) and also in ton. This has nothing to do with weight, it is a measurement of heat; 1 ton $=12,000 \mathrm{Btu}$. In determining the ton of AC needed in a building, vital factors such as the building regular high temperature, the orientation of the building, the windows, shading, the insulative values of the walls, windows, doors, and roofing, internal loads, and solar gain are taken into cognisance. The internal loads will include persons habiting the space, the appliances in the room, and the illuminations in the room.

The best way to size your AC system is to have a "Manual J" calculation done on the building because it takes into account the above-mentioned factors. According to Bluejay (2016), since we are considering only cooling, the rule of thumb is enough to size our AC equipment, it goes thus: 1 ton of cooling is for every $55.742 \mathrm{Sqm}$ of a building. Hence,

$$
\text { HVAC Size }=\text { Area of room }(S q m) X \frac{1 \text { ton }}{55.742 m^{2}}
$$

Energy efficiency ratio of an HVAC system (EER) is the ratio of the amount of cooling produced (BTU) to the amount of electricity (Watt) used. Mathematically expressed as

$$
E E R=\frac{\text { Heat }}{\text { Power }}
$$

\section{METHODOLOGY}

\section{A. The Specimen Building}

The specimen building is Hall "E", a computer-based test centre in the University of Ilorin, Ilorin, Nigeria. The reason for the choice of a sandcrete-walled structure is because the majority of the buildings in Nigeria are built with hollow sandcrete blocks (Arup \& Genre, 2016) and the reason for the choice of this building specimen is because the University computer-based test centre fits a great building in which the energy consumption is enormous. Consequently, it is suitable to conduct a study in this area.

The specimen building is not a storey building and has no room partition. It is a computer room with a rectangular geometry and has its shorter sides west oriented with two doors, and the longer sides north oriented with eight windows. The building dimension was determined with a measuring tape and measured to be $22 \mathrm{~m}$ by $15 \mathrm{~m}$ by $3 \mathrm{~m}$, with a net floor area of $330 \mathrm{~m}^{2}$, all the walls are adjacent to the outdoor environment, and it was conceived to be a one-zone model. As at the time of this analysis, there were 250 candidates writing their computer-based examination in the building, the room temperature was taken to be $26^{\circ} \mathrm{C}$ at $10: 00$ am, with a laboratory thermometer. There were four standing split air conditioner system in the building, each having a thermostat value of $26^{\circ} \mathrm{C}$. The reference building was assumed to be in use from 8:00 am to 5:00 pm (peak period), Monday through to Friday, January 1st, 2018 to mid of September 2018.

The air conditioning system, computers and Lighting were always powered on an hour before the opening time. Twenty units of 20W Compact Fluorescent Light (CFL) bulb kept the brightness of the reference building lower than the standards (300 lux, (Arup \& Genre, 2016)), with the absence of daylight controls to reduce the electric light energy use. The ratings of the appliances present in the building were determined by checking their respective labels. The interior of the reference building is shown in Figure 1.

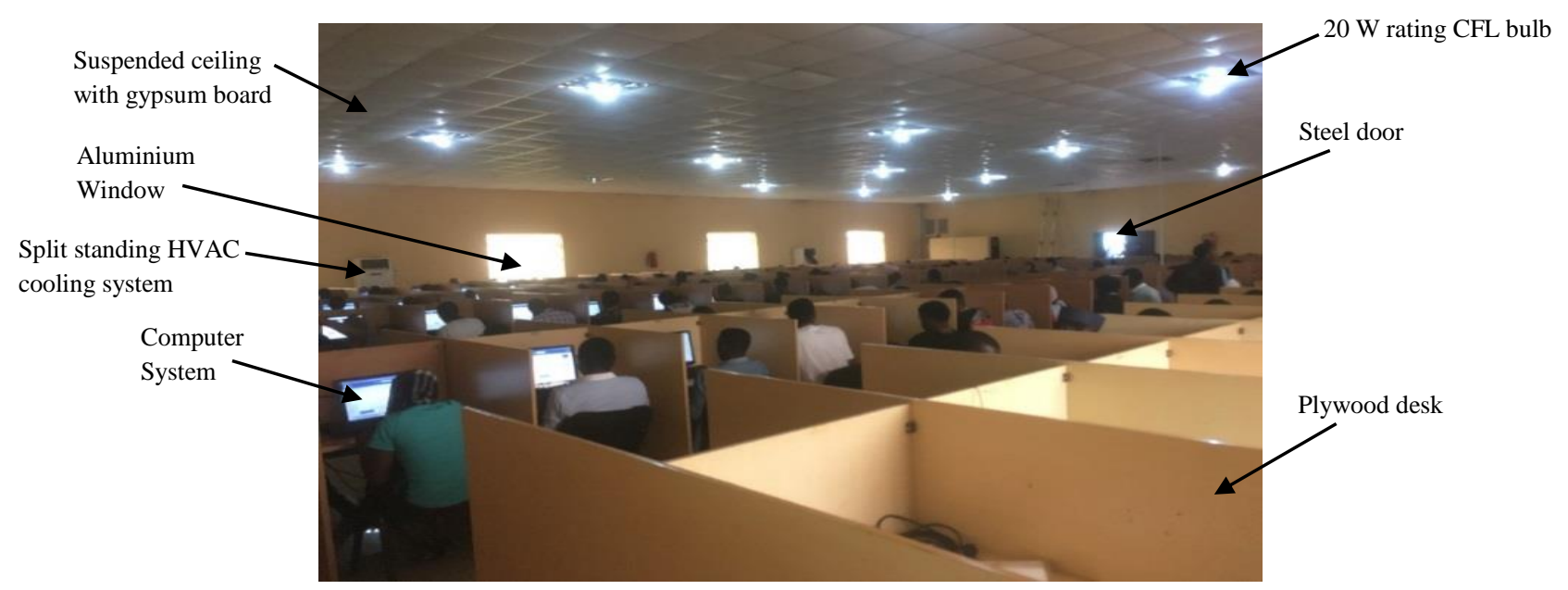

Figure 1: The interior of the specimen building. 


\section{B. Description of the Control Building}

The control building was modelled to be a replicate of the specimen building in terms of schedule, geometry, orientation and size but with the application of recommendations by the Building Energy Efficiency Guideline (BEEG) for Nigeria. The BEEG gives professionals practical advice on how to design, construct and operate energy efficient buildings that are relevant and appropriate for the Nigerian climate. There are two variants of the control building according to construction materials, which are stated as follows:

\section{1.) The Hollow Sandcrete-walled building}

This is the first variant of the control building. It was modelled to be built with hollow sandcrete block with U-value $=1.6 \mathrm{~W} / \mathrm{m}^{2} \mathrm{~K}$, the walls were insulated with one inch polystyrene, the window glazing was modelled to be double glazing, with solar control and soft coating in order to reduce the solar gains in the building. The roof was modelled as a naturally ventilated pitched metal sheeting roof with insulation. Multi-unit AC system was used in the building model, in which the indoor units are affixed to the wall and ceiling. It was sized in response to the actual demand of the building. In this control building, LED lights were used. The LED were used because it doesn't emit high levels of heat and they don't contain toxic chemicals (LEDlights.org, 2019). A double daylight and occupancy control sensor was placed in the centre along the length of the building. Continuous dimming was selected as the method of daylighting control. The standard brightness of a computer room (300 LUX (Arup \& Genre, 2016)) was achieved with very minimal energy. The computers in the building were modelled to be laptop computers, Equipment Energy-Efficient software was installed which automatically and safely sleep computer when not in use or shuts down computers at night in case staff forget to do so before leaving.

\section{2.) The hollow burnt brick building}

This is the second variant of the control building. It was modelled to be built with a hollow burnt brick building, while other conditions were modelled like the first variant of the control building in terms of geometry, orientation, schedule, and electrical equipment. The typical layout plan of the specimen and control building is shown in Figure 2 .
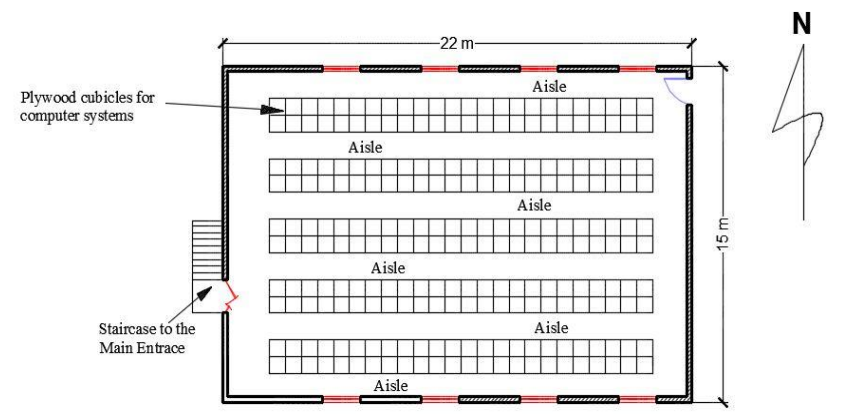

Figure 2. The typical layout plan for the specimen building and control building.

\section{Building Energy Analysis}

The analysis of the energy performance of the specimen building as well as that of the control building was conducted using eQUEST software tool. The Schematic Design Wizard was used to create the building description in eQUEST, the weather data file for Lagos State, Nigeria was imported into the software, and the data shown in Table 3 were also inputted in the wizard to perform the analysis. The weather data file for Lagos state was used for the analysis because it was the only weather data file in BIN format available for Nigeria and acceptable to the eQUEST software as at the time the analysis was conducted.

In Table 3, following the laid down principle by the BEEG, the load appliances in the specimen building were replaced by

Table 3. Model of specimen building and control building.

\begin{tabular}{|c|c|c|}
\hline $\begin{array}{l}\text { Building } \\
\text { Envelope }\end{array}$ & Building Specimen & Building Control \\
\hline Wall & $\begin{array}{l}\text { Hollow sandcrete wall, } \mathrm{U}= \\
1.5 \mathrm{~W} / \mathrm{m}^{2} \mathrm{~K}\end{array}$ & $\begin{array}{l}\text { Hollow sandcrete wall, } \mathrm{U}=1.5 \\
\mathrm{~W} / \mathrm{m}^{2} \mathrm{~K} \text {, (Arup \& Genre, 2016) } \\
(\mathrm{In} \text { comparison, Burnt Brick, } \mathrm{U}= \\
\left.0.6 \mathrm{~W} / \mathrm{m}^{2} \mathrm{~K}(\mathrm{Carl}, 2017)\right)\end{array}$ \\
\hline Roof & $\begin{array}{l}\text { Pitched metal sheeting roof } \\
\text { without insulation }\end{array}$ & $\begin{array}{l}\text { Naturally ventilated pitched metal } \\
\text { sheeting roof with insulation }\end{array}$ \\
\hline $\begin{array}{l}\text { External shading } \\
\text { to windows }\end{array}$ & Absent & Present \\
\hline Computer & Desktop $=27,500 \mathrm{~W}$ & Laptop $=11,750 \mathrm{~W}$ \\
\hline HVAC & $\begin{array}{l}4 \text { units of split Air } \\
\text { Conditioner }\end{array}$ & $\begin{array}{l}2 \text { units of Multi-unit A / C } \\
34100 \times 2=68,200 \mathrm{Btu} / \mathrm{h}\end{array}$ \\
\hline $\begin{array}{l}\text { Cooling capacity } \\
\text { - Power } \\
\text { - Efficiency }\end{array}$ & $\begin{array}{l}4 \times 25000=100,000 \mathrm{Btu} / \mathrm{h} \\
4 \text { units } \times 3.3 \mathrm{~kW}=13.2 \mathrm{~kW} \\
100,000 / 13.2 \mathrm{~kW}=7.58\end{array}$ & $\begin{array}{l}2.9 \mathrm{~kW} \times 2=5.8 \mathrm{~kW} \\
68,200 / 5.8 \mathrm{~kW}=11.76\end{array}$ \\
\hline $\begin{array}{l}\text { Lighting } \\
\text { - Load } \\
\text { - Brightness }\end{array}$ & $\begin{array}{l}\text { CFL } \\
1.20 \mathrm{~W} / \mathrm{m}^{2} \text {, } \\
1210 \mathrm{X} 20 / 330=73 \mathrm{LUX} \text {, } \\
\text { which does not meet the } \\
\text { required brightness for the } \\
\text { building according to Arup } \\
\text { and Genre (2016) }\end{array}$ & $\begin{array}{l}\text { LED + Daylight Sensor } \\
2.73 \mathrm{~W} / \mathrm{m}^{2} \\
2780 \times 36 / 330=300 \mathrm{LUX} \text { which } \\
\text { meet the required brightness for } \\
\text { the building according to Arup and } \\
\text { Genre }(2016) \text {. }\end{array}$ \\
\hline Plug Load & $83.3 \mathrm{~W} / \mathrm{m}^{2}$ & $35.61 \mathrm{~W} / \mathrm{m}^{2}$ \\
\hline
\end{tabular}

more energy-efficient load appliances in the control building. The eQUEST schematic design wizard interface is shown in Figure 3.

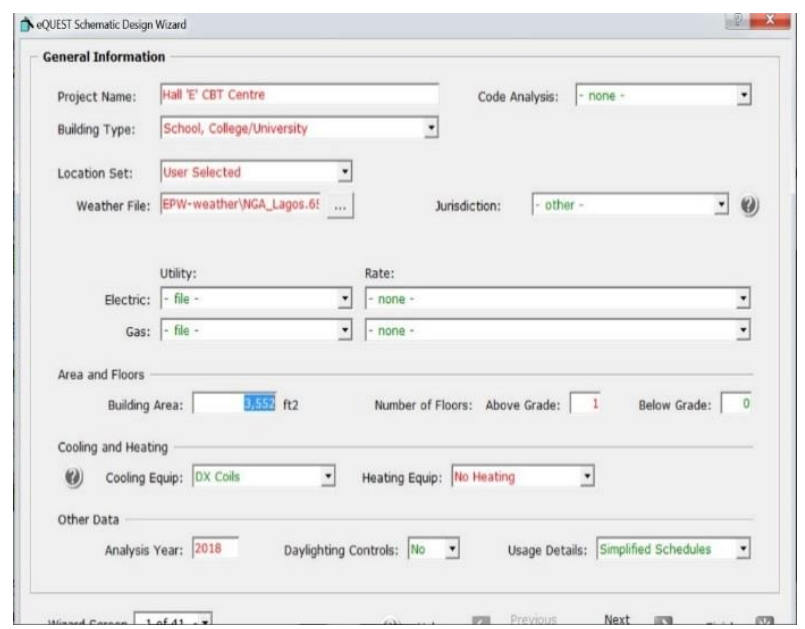

Figure 3. General information of the specimen building in eQUEST. 


\section{Exergy Analysis}

In 2012, Lidholm et al, (2012) explained that to simplify the calculations including exergy in energy transformation there is a method for converting energy to exergy, via the exergy factor. The exergy factor is explained as the ratio of Exergy to Energy, expressed as

Exergy Factor $=\frac{\text { Exergy } E}{\text { Energy } Q}$

From equation (5), Exergy = Exergy factor $\mathrm{x}$ Energy

When the energy temperature is constant but differs from the surroundings, the exergy factor can be defined as

$$
\frac{E}{Q}=\frac{T-T_{0}}{T} \text { (Lidholm et al., 2012) }
$$

Where $\mathrm{T}_{0}$ is the surrounding absolute temperature and $\mathrm{T}$ is the absolute temperature in the object.

Itard (2005) explains that ventilators, appliances and Lighting are electrical equipment. For all electrical equipment, an exergetic efficiency of one is applied, which is consistent with Molinari (2009) that assert that the Exergy factor of electricity is 1 couple with equation (6) by Lidholm, (2012). Therefore:

$$
E_{\text {light, ventil, appl }}=Q_{\text {light, ventil, appl }}
$$

Where $E_{\text {appl }}=$ Exergy of appliances, $E_{\text {ventil }}=$ Exergy of Air conditioning system, $E_{\text {light }}=$ Exergy of lighting, $Q_{\text {appl }}=$ Energy of appliances, $Q$ ventil $=$ Energy of Air conditioning system, $Q$ light $=$ Energy of lighting. Their respective unit is Joule.

\section{RESULTS AND DISCUSSION}

\section{A. Energy Analysis of the Buildings}

\section{1.) Specimen Building}

Simulation of the specimen building was successfully completed in the eQUEST software and the simulation result of the monthly electric consumption of the specimen building and annual electric consumption are shown in Figures 4 and 5 respectively.

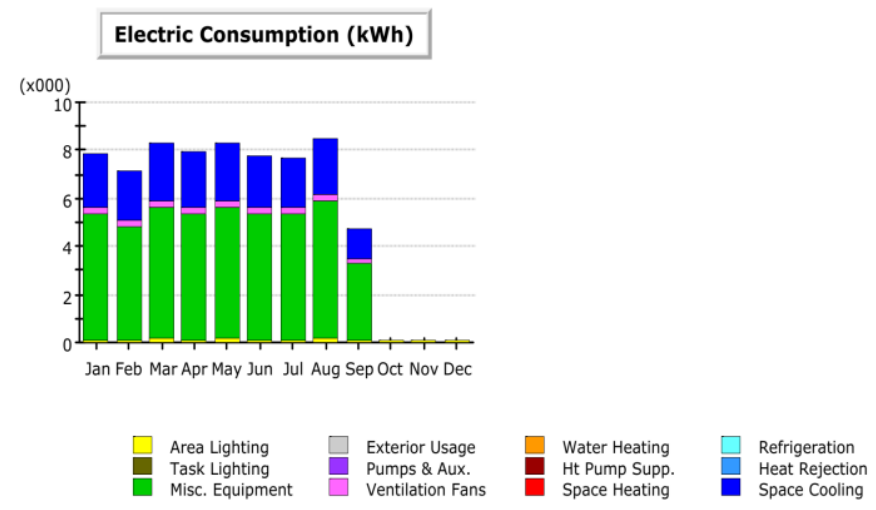

Figure 4. The monthly consumption of the specimen building by end-use.

The bar chart depicts that the largest electric consumption was up to $8440 \mathrm{kWh}$ in the month of August, However, the minimum electric consumption was only $70 \mathrm{kWh}$ in October, as a result of inactivity of the building during this period except in the night when the security lights were powered on. Electric consumption in October is about $0.82 \%$ of the electric consumption in August.

During the holidays, the building was closed for examination purposes, thus, the energy consumption from October to December was minimal. The total annual energy for the year 2018 consumption by end-use of the specimen building was $68,354 \mathrm{kWh}$. Based on the pie chart representation, it was depicted that $45,470 \mathrm{kWh}, 21,510 \mathrm{kWh}$, and $1,370 \mathrm{kWh}$ of the energy were consumed by the equipment (Computer systems), space cooling \& Ventilation fans and Area lighting respectively.

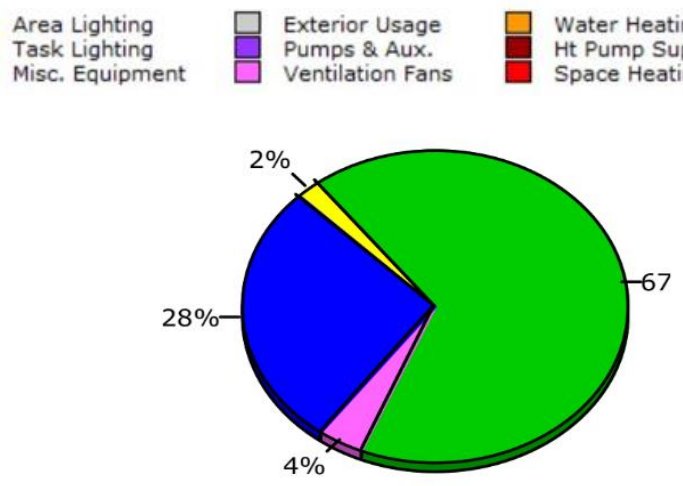

Figure 5. The Annual Electric Consumption by End-use of the Specimen Building.

Considered by the building area of $330 \mathrm{~m}^{2}$, the yearly energy consumption of the specimen building per unit area was $240 \mathrm{kWh} / \mathrm{m}^{2}$, which does not fall under the category of good practice air conditioned office according to Arup and Genre (2016). The largest percentage of energy was consumed by the computer systems in the building while the least electric energy was consumed by area lighting. From the results above, it can be established that the annual energy consumption is consistent with the actual operation of the specimen building.

\section{2.) Control Building}

\section{a. The Hollow Sandcrete-walled building}

The results of the hollow sandcrete-walled building energy simulation are shown in Figures 6 and 7. The bar chart showed that the principal power consumption was up to $4,640 \mathrm{kWh}$ in March. However, the least power consumption was only 30 $\mathrm{kWh}$ in October as well as November and December, which is $0.65 \%$ of electric consumption in March.
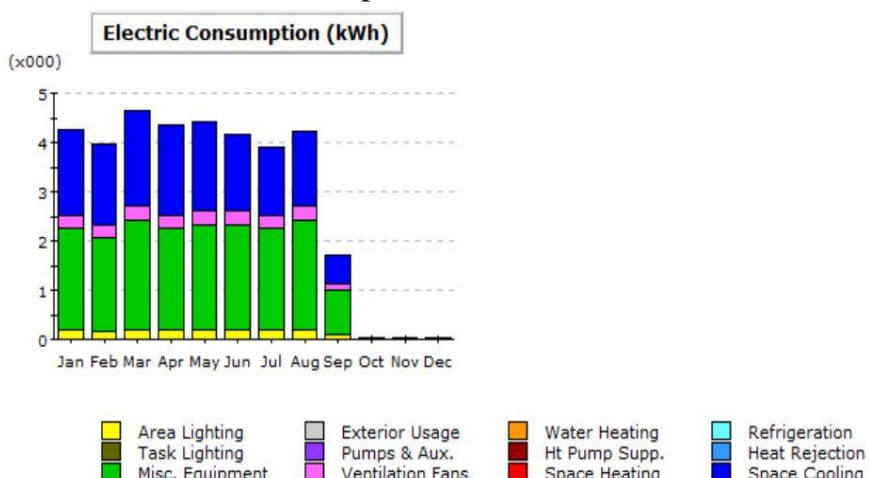

Misc. Equipm Pumps \& Aux.
Ventilation Fan

tt Pump Supp.

Space Cooling

Figure 6. The monthly consumption of the hollow sandcrete building by end-use. 
The total annual energy for the year 2018 consumed by the hollow sandcrete-walled building is $35,735 \mathrm{kWh}$. Based on the pie chart representation, it was observed that $17,684 \mathrm{kWh}$, $16,314 \mathrm{kWh}$, and $1,737 \mathrm{kWh}$ of the energy were consumed by the equipment (Computer systems), space cooling \& Ventilation fans and Area lighting respectively.
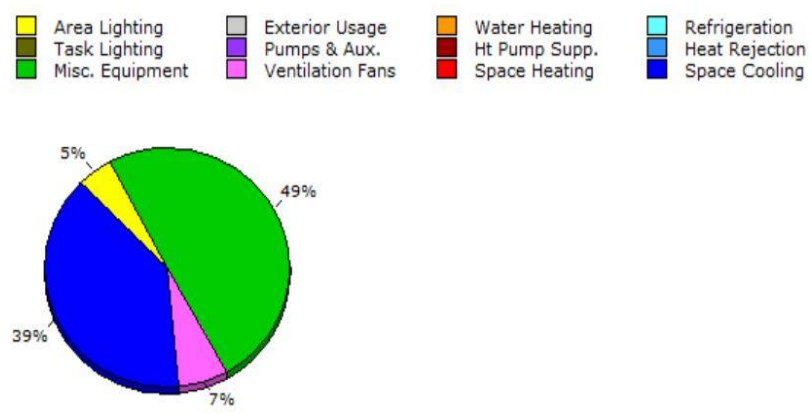

Electricity

Figure 7. Annual Electric Consumption of the Control Building.

Which depicts that largest percentage of energy is consumed by the Computer systems in the building while the least electric energy is consumed by area lighting. Calculated by the whole building area of $330 \mathrm{~m}^{2}$, the annual energy consumption of the hollow sandcrete-walled building per unit area was $108 \mathrm{kWh} / \mathrm{m}^{2} /$ year which falls under $130 \mathrm{kWh} / \mathrm{m}^{2} /$ year (Arup and Genre, 2016), and thus can be categorized as a best practice air conditioned office.

\section{b. Hollow Burnt Brick walled building}

The results of the hollow burnt brick building simulation are shown in Figures 8 and 9. The bar chart representation of the monthly electrical consumption by end use in the brick building is shown in Figure 8. The result shows that the largest electric consumption was up to $4630 \mathrm{kWh}$ in March while the minimum was only $30 \mathrm{kWh}$ in October, as well as November and December.

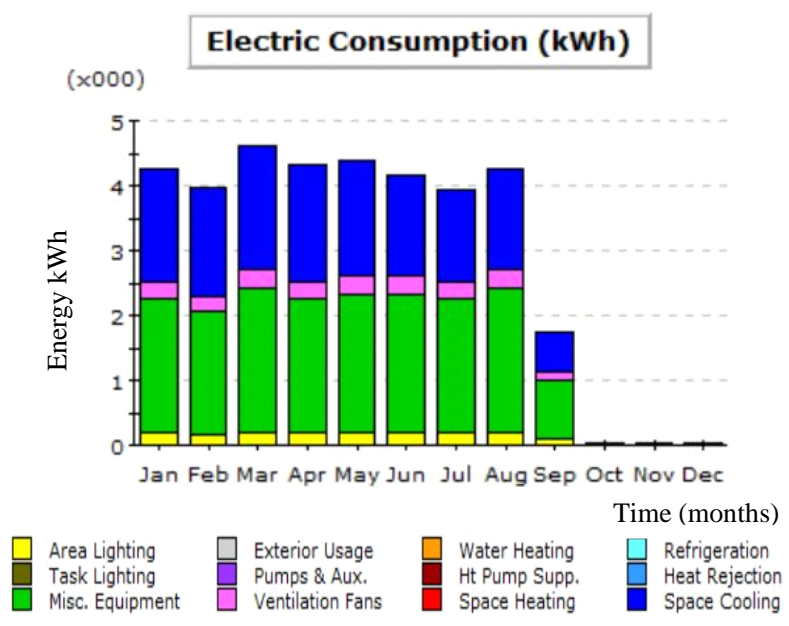

Figure 8. Monthly Electrical consumption by End use in the Burnt Brick Building
The total annual energy consumed by the burnt brickwalled building is $35,721 \mathrm{kWh}$, and it is represented on a pie chart in Figure 9. Based on the pie chart representation, it can be depicted that the amount of energy consumed by the laptops, air conditioner and area lighting systems were 17,684 $\mathrm{kWh}, 16300 \mathrm{kWh}$, and 1,737 $\mathrm{kWh}$ respectively. Which portrays that the largest percentage of energy is consumed by the computer systems in the building while the least energy is consumed by the area lighting. The annual energy consumption of the brick building per unit area is 108 $\mathrm{kWh} / \mathrm{m}^{2} /$ year which falls under $130 \mathrm{kWh} / \mathrm{m}^{2} /$ year (Arup \& Genre, 2016) and thus, it can be categorized as a best practice air conditioned office.

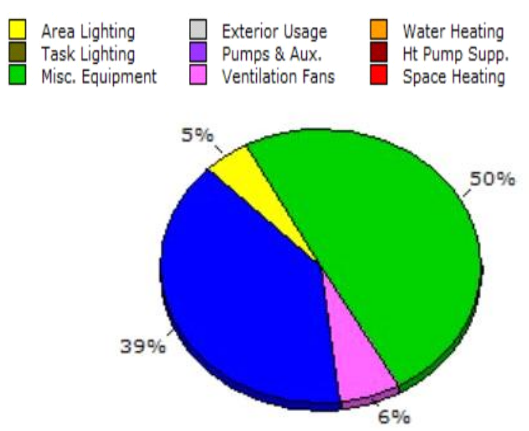

Electricity

Figure 9. Annual Electrical Consumption by End use in the Burnt Brick Building

\section{B. Exergy Analysis}

Exergy analysis was conducted as shown in equation (6). The exergy demand of the computer systems, AC system and area lighting were calculated using equation (8). Hence, the cumulative exergy consumption of the specimen and control building is equal to their respective energy demand. The fundamental unit of Exergy is Joule, thus the result will be converted from $\mathrm{kWh}$ to Mega Joule/year and represented in a bar chart.

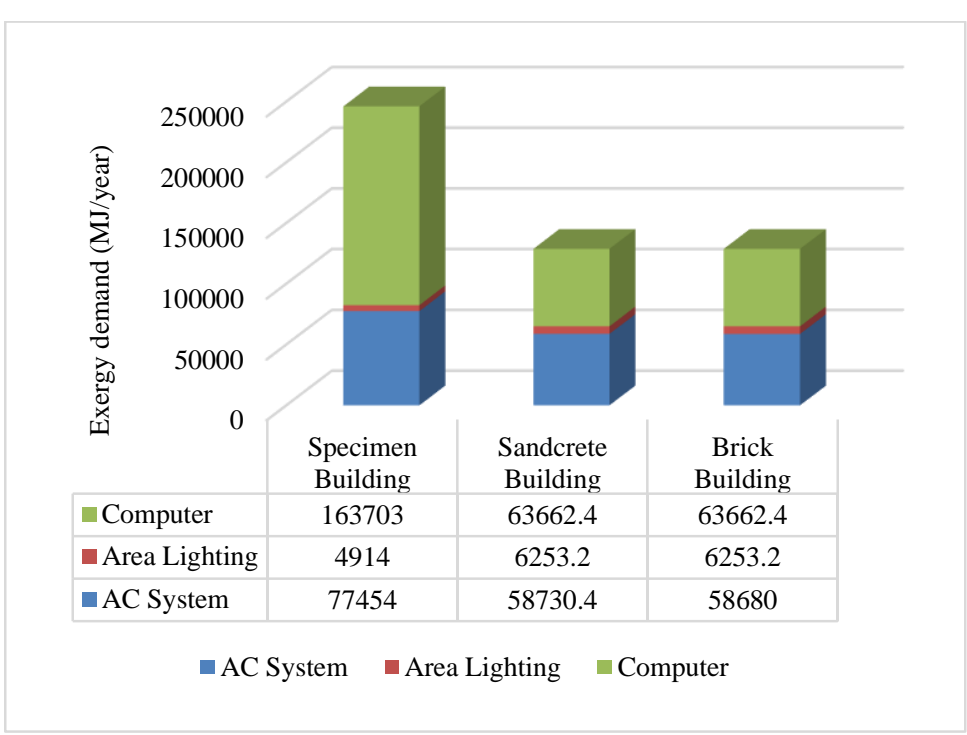

Figure 10. Cumulative exergy consumption of the specimen building and the variants of control building. 
The exergy consumption of the control building was observed to be significantly lesser than that in the specimen building as a result of the building airtightness improvement, naturally ventilating the roof, utilizing extremely efficient systems, and window design improvement in the control building. On the other hand, the lighting exergy consumption in the control building was found to be greater than that in the specimen building as a result of the control building being designed to meet the required brightness for a computer room (300 lux); the higher the brightness, the more exergy is consumed. While the specimen building (73 lux) did not meet the required brightness for the computer room (according to Arup and Genre (2016)).

\section{CONCLUSIONS AND RECOMMENDATIONS}

A. Conclusions

a) The data necessary for conducting the exergy analysis were acquired by visiting the existing building and employing standard measuring equipment to determine their respective measurements. The annual energy consumption of the existing building per unit area was estimated to be $240 \mathrm{kWh} / \mathrm{m}^{2} /$ year, which was categorized as not a good practice for an air conditioned office, while the annual energy consumption of the variants of control building per unit area was $108 \mathrm{kWh} / \mathrm{m}^{2} /$ year which was categorized as best practice for an air conditioned office.

b) The cumulative exergy consumptions of the specimen building, hollow sandcrete and burnt brick-walled building were found to be $246,074.4 \mathrm{MJ} /$ year, 128,646 MJ/year, and 128,595.6 MJ/year respectively. The sandcrete building, as well as the burnt brick building, were found to be $48 \%$ more energy efficient than the specimen building as a result of the building airtightness improvement, the solar heat gain reduction, and the utilization of extremely efficient systems.

c) The exergy analysis suggested that the burnt brick building performed better, and is more sustainable than the hollow sandcrete walled building, as it was able to save extra 50.4 MJ in the electricity demand for air conditioning. This is as a result of the low thermal conductance value of the burnt bricks which greatly reduces the heat gain in the building.

\section{B. Recommendations}

a) For long term sustainability, structures built with burnt bricks are more appropriate than hollow sandcrete walled structures.

b) In the design phase of a building, the operational cost, energy efficiency and thermal comfort of the occupants should be highly considered by the design engineers.

c) Since the case study is located in a tropical sub-region a more sustainable source of generating electricity based on solar and/or wind should be adopted.

\section{REFERENCES}

Abdullahi, M. (2005). Compressive strength of sandcrete blocks in Bosso and Shiroro areas of Minna, Nigeria. Assumption University Journal of Technology, 9(2), 126-131.

Adedeji, A. A. and Fa, G. (2012). Sustainable housing provision: Preference for the use of interlocking masonry in housing delivery in Nigeria. Architecture Research, 2(5), 8186.

Arup, O. and Genre, D. (2016). Building Energy Efficiency Guideline for Nigeria. Abuja: Federal Ministry of Power, Works and Housing.

Bluejay, M. (2016). HVAC Sizing. Retrieved 24th June, 2019, from www.michaelbluejay/hvac-sizing.html

Carl, R. N. (2017). Thermal Conductivity. Retrieved 27th June, 2019, from http://www.hyperphysics.phyastr.gsu.edu/hbase/Tables/thren.html

Ilari, A. (2007). Integrated building and system design for increased exergy performance reHVAClub Seminar (pp. 1-8). Berlin.

Itard, L. (2003). H.e.n.k., a software tool for the integrated design of buildings and installations in the early design stage. Paper presented at the Proceedings Eight International IBPSA Building Simulation Conference, Eindhoven, Netherlands.

Itard, L. (2005). Analysis of the exergy-consumption of four types of buildings. Paper presented at the The 2005 World Sustainable Building Conference, Tokyo.

Jian, A. (2018). How much lighting is good lighting for a room? Retrieved 11th October, 2018, from https://www.bijlibachao.com/lights/how-much-lighting-isgood-lighting-for-a-room.html

Laaroussi, N.; A. Cherki; M. Garoum; A. Khabbazi and A. Feiz. (2013). Thermal properties of a sample prepared using mixtures of clay bricks. Energy Procedia, 42, 337-346.

LEDlights.org. (2019). Do LED Lights Produce Heat. Retrieved 1st June, 2019, from http://www.ledlights.org/FAQ/Do-LED-Lights-ProduceHeat.html

Lidholm, M.; C. Odelbrink and J. Sandwall. (2012). Exergy Analysis of two Residential Buildings with Wooden and Concrete Frame.

Lou, S.; E. K. Tsang; D. H. Li; E. W. Lee and J. C. Lam. (2017). Towards zero energy school building designs in Hong Kong. Energy Procedia, 105, 182-187.

Mahlia, T.; B. Taufiq; K. Ong and R. Saidur. (2011). Exergy analysis for day lighting, electric lighting and space cooling systems for a room space in a tropical climate. Energy and Buildings, 43(7), 1676-1684.

Molinari, M. (2009). Exergy Analysis in Buildings: A complementary approach to energy analysis. (Doctoral dissertation), Byggvetenskap.

Mooney, B. L. and Porter, W. A. (2010). Internal Microclimate Resulting From Ventilated Attics in Hot and Humid Regions. http://www.googlescholar.com/internalmicroclimate-resulting-from-ventilated-attics-in-hot-humid$\underline{\text { regions }}$

Odeyemi, S. (2012). Effect of types of sandcrete blocks on the internal microclimate of a building. Journal of Research Information in Civil Engineering (RICE), Department of Civil Engineering, University of Ilorin, Ilorin, Nigeria, 9, 96-107. 
Sakulpipatsin, P. (2008). Exergy efficient building design. Journal of Sustainable building, 8(3).

Sakulpipatsin, P.; L. Itard; H. Van der Kooi; E. Boelman. and P. Luscuere. (2010). An exergy application for analysis of buildings and HVAC systems. Energy and Buildings, 42(1), 90-99.

Santamouris, M. (2013). Heat Island Effect, Energy and climate in the urban built environment. London: Routledge.
Seaman, G. (2011). LED bulbs are ready to light your home: 7 tips you should know. Retrieved 11th October, 2018, from http://eartheasy.com/blog/2011/08/led-bulbs-are-readyto-light-your-home-7-tips-you-should-know/

Shibib, K. S.; H. I. Qatta and M. S. Hamza. (2013). Enhancement in thermal and mechanical properties of bricks. Thermal Science, 17(4), 1119-1123. 